\title{
ASPEK HUBUNGAN DEWAN PERWAKILAN RAKYAT DAN PRESIDEN DALAM PEMBAHASAN BERSAMA SUATU UNDANG-UNDANG
}

Oleh:

Ichsan Anwary

\begin{abstract}
The term "holding authority" according to Article 20 (1), Constitution of 1945, Indonesia means as an obligation. House of Representative holding authority to establish laws refer to a its authority to propose Draft of Laws.

Formulation or construction concerning on authority on establishing laws, which regards to three state institutions: House of Representative, President and Regional Representative Council is not designed in a complete and best design.
\end{abstract}

Keywords: Establishing laws, hold authority, consentience.

\section{PENDAHULUAN}

Perubahan Pertama Undang-Undang Dasar 1945 telah membawa perubahan yang mendasar terhadap 2 (dua) aspek yakni pertama, pembatasan kekuasaan presiden, dan kedua, pemberdayaan lembaga legislatif. Perubahan Pertama UndangUndang Dasar 1945 ini menunjukkan seakan-akan peranan Dewan Perwakilan Rakyat sekarang ini semakin menguat. Apabila dahulu pada masa Undang-Undang Dasar 1945 sebelum dilakukan perubahan dikenal adanya executive heavy, maka sekarang ini dengan dukungan peraturan perundang-undangan yang ada perkembangan peranan Dewan Perwakilan Rakyat telah menjurus kepada legislative heavy.

Dewan Perwakilan Rakyat periode sekarang (2014 - 2019) telah memutuskan dengan Keputusan DPR RI Nomor: 06A/DPR RI/II/2014-2015 tentang Program Legislasi Nasional Tahun 2015-2019 Dan
Program Legislasi Nasional Rancangan Undang-Undang Prioritas Tahun 2015 Hasil Pembahasan Tripartit (DPR, DPD, Pemerintah) Prioritas Tahun 2015 - 2019. Terdapat 160 Rancangan Undang-Undang (RUU) usul Prolegnas Tahun 2015 - 2019.

Dari sejumlah daftar inventarisasi RUU dalam Prolegnas di atas lembaga pengusul terdiri dari DPR, DPD, Pemerintah, DPR/DPD/Pemerintah, DPR/DPD, DPD/Pemerintah. Malahan diklaim oleh DPD bahwa dari 160 RUU usul Prolegnas Tahun 2015-2019, 52 RUU ternyata sesuai dengan usul Prolegnas DPD. ${ }^{1}$

Perkembangan kemudian dari hubungan kelembagaan dalam pembentukan sebuah Undang-undang dijabarkan dalam berbagai peraturan perundang-undangan baik dalam Undang-undang tentang MPR, DPR, DPD, dan DPRD maupun dalam Undang-undang

\footnotetext{
1 Lihat Prolegnas Usul DPD RI Tahun 2015-2019, Prioritas 2015 dan Hasil Pembahasan Tripartit (DPR, DPD dan Pemerintah) Tahun 2015 - 2019 Prioritas Tahun 2015, Penerbit PPUU-DPD RI, Tahun 2015
} 
yang mengatur tentang pembentukan peraturan perundang-undangan.

Berkenaan dengan pemegang kekuasaan membentuk undang-undang sebelum perubahan Undang-Undang Dasar 1945 dapat dilihat dalam ketentuan Pasal 5 ayat (1) dan Pasal 20 ayat (1) Undang-Undang Dasar 1945. Apabila ketentuan UndangUndang Dasar 1945 sebelum perubahan pertama mengatur dalam Pasal 5 ayat (1): Presiden memegang kekuasaan membentuk Undang-Undang dengan persetujuan Dewan Perwakilan Rakyat. Pasal 20 ayat (1) menyatakan bahwa tiap-tiap UndangUndang menghendaki persetujuan Dewan Perwakilan Rakyat maka Pasal 5 ayat (1) Undang-Undang Dasar 1945 setelah mengalami perubahan menyatakan Presiden berhak mengajukan rancangan undangundang kepada Dewan Perwakilan Rakyat. Pasal 20 ayat (1) Undang-Undang Dasar 1945 setelah perubahan menyatakan: Dewan Perwakilan Rakyat memegang kekuasaan membentuk undang-undang. Ketentuan Pasal 5 ayat (1) yang lama menjadi berbalik dengan ketentuan Pasal 20 ayat (1) yang baru dalam hal kewenangan membentuk undang-undang. Dengan kata lain berarti Dewan Perwakilan Rakyat telah berubah menjadi pemegang utama kekuasaan membentuk undang-undang dan kewenangan mengatur (regel) tidak lagi berada di tangan Presiden. Presiden sudah berubah menjadi pelaksana belaka (eksekutif) terhadap segala keputusan legislatif dalam bentuk undang-undang yang ditetapkan oleh Dewan Perwakilan Rakyat.

Berkenaan dengan perubahan Pasal 20 ayat (1) diatas, kemudian diiringi dengan ketentuan Pasal 20 ayat (2) Setiap rancangan undang-undang dibahas oleh Dewan
Perwakilan Rakyat dan Presiden untuk mendapat persetujuan bersama; ayat (3) Jika rancangan undang-undang itu tidak mendapat persetujuan bersama, rancangan undang-undang itu tidak boleh diajukan lagi dalam persidangan Dewan Perwakilan Rakyat masa itu; ayat (4) Presiden mengesahkan rancangan undang-undang yang telah disetujui bersama untuk menjadi undang-undang. Ketentuan Pasal 20 sebanyak 4 (empat) ayat di atas yang terdapat dalam Perubahan Pertama ini kemudian ditambahkan lagi dalam Perubahan Kedua Undang-Undang Dasar 1945 Agustus tahun 2000 dengan ayat (5) Dalam hal rancangan undang-undang yang telah disetujui bersama tersebut tidak disahkan oleh Presiden dalam waktu tiga puluh hari semenjak rancangan undangundang tersebut disetujui, rancangan undang-undang tersebut sah menjadi undang-undang dan wajib diundangkan.

Perubahan Kedua UUD 1945 telah mengintrodusir lembaga negara baru yakni Dewan Perwakilan Daerah sebagaimana diatur dalam Bab VIIA Dimulai dari Pasal 22C, dan Pasal 22D. Dalam salah satu kewenangan DPD ditegaskan dalam Pasal 22D ayat (2) bahwa DPD ikut membahas rancangan undang-undang yang berkaitan dengan otonomi daerah; hubungan pusat dan daerah; pembentukan, pemekaran, dan penggabungan daerah; pengelolaan sumber daya alam dan sumber daya ekonomi lainnya., serta perimbangan keuangan pusat dan daerah;.....dst.

Pertanyaan hukum dari kewenangan DPD di atas, adalah apa makna ikut membahas dalam frasa di atas.

Berdasarkan hal yang dipaparkan di atas menjadi keniscayaan untuk melakukan 
telaah tentang aspek hubungan kelembangan antara DPR dan Pemerintah dalam melakukan pembahasan bersama suatu undang-undang.

\section{PEMBAHASAN}

Dalam konteks menelaah kekuasaan Dewan Perwakilan Rakyat sebagai pemegang kekuasaan membentuk Undangundang sebagaimana ditegaskan dalam Pasal 20 ayat (1) UUD Negara RI Tahun 1945: Dewan Perwakilan Rakyat memegang kekuasaan membentuk undangundang dan menilai aspek hubungan antara Dewan Perwakilan Rakyat dan Presiden dalam pembentukan Undang-undang sebagaimana ditegaskan dalam rumusan Pasal 20 ayat (2) UUD Negara RI Tahun 1945: Setiap rancangan undang-undang dibahas oleh Dewan Perwakilan Rakyat dan Presiden untuk mendapat persetujuan bersama. Maka layak untuk melakukan penelaahan dan penelusuran terhadap perkembangan pemikiran dan pendapat dalam literatur lama sebelum UndangUndang Dasar 1945 dilakukan perubahannya.

A.. Hamid S Attamimi dalam disertasinya "Peranan Keputusan Presiden Republik Indonesia Dalam Penyelenggaraan Pemerintahan Negara Suatu Analisis Mengenai Keputusan Presiden Yang Berfungsi Pengaturan Dalam Kurun Waktu Pelita I - Pelita IV" menegaskan kekuasaan legislatif dijalankan oleh Presiden dengan persetujuan DPR. Kekuasaan pembentukan undang-undang berada pada Presiden, tidak pada DPR. ${ }^{2}$ Pendapat A. Hamid S Attamimi

2 A. Hamid S. Attamimi, Peranan Keputusan Presiden Republik Indonesia Dalam Penyelenggaraan Pemerintahan Negara Suatu ini didasarkan pada ketentuan Pasal 5 ayat (1) Undang-Undang Dasar 1945 yang menyebutkan : Presiden memegang kekuasaan membentuk Undang-undang dengan persetujuan Dewan Perwakilan Rakyat. Bahwa jelas secara harfiah Presiden lah yang memegang kekuasan membentuk Undang-undang, sedang DPR berfungsi memberi (atau tidak memberi) persetujuan terhadap pelaksanaan kekuasaan yang berada pada Presiden. ${ }^{3}$ Di dalam Penjelasan ${ }^{4}$ UUD 1945 mengenai Pasal 5 ayat (1) menyebutkan: Kecuali executive power, Presiden bersama-sama dengan Dewan Perwakjilan Rakyat menjalankan legislative power dalam negara. Pengertian bersama-sama dalam Penjelasan di atas, Undang-Undang Dasar 1945 tidak menjelaskan dan tidak merinci apa yang dimaksudkannya.

A. Hamid S. Attamimi untuk menelaaah lebih mendalam pengertian bersama-sama, ia telah merangkum sejumlah pendapat para pakar hukum tata negara yang memberikan ulasan dan pembahasan terhadap pengertian bersama-sama dimaksud. Istilah A. Hamid S. Attamimi terhadap penelaahan dimaksud adalah "mengkounsultasikannya" dengan para ahli hukum tata negara Indonesia. ${ }^{5}$

A. Hamid S. Attamimi memulai dengan merujuk pendapat Ismail Suny dalam disertasinya yang berjudul "Pergeseran Kekuasaan Eksekutif (1963) yang tidak menjelaskan apa yang dimaksud dengan kata-nata "bersama-sama". Ia hanya

Analisis Mengenai Keputusan Presiden Yang Berfungsi Pengaturan Dalam Kurun Waktu Pelita I Pelita IV', Disertasi, Jakarta: Universitas Indonesia, 1990 hlm. 146

${ }^{3}$ Ibid.

${ }^{4}$ Pasca Perubahan UUD 1945 kedudukan Penjelasan UUD 1945 tidak ada lagi.

${ }^{5}$ A. Hamid, op.cit. hlm. 147 
menunjuk kepada Ketetapan MPR Nomor II/MPRS/1960 yang antara lain merumuskan tugas dan wewenang Presiden. ${ }^{6}$ A Hamid S Attamimi merujuk pendapat Wirjono Prodjodikoro yang dinilainya tidak memberikan pemahaman yang terperinci mengenai pengertian "memegang kekuasaan" dan "dengan persetujuan" dalam Pasal 5 ayat (1) UUD 1945. Ia hanya menguraikan: dari Pasal 5 ayat (1) dan Pasal 20 ayat (1) Undang-Undang Dasar tersebut di atas, ternyata bahwa apa yang dinamakan Undang-undang ialah hanya peraturan peraturan yang dibentuk atas kerjasama antara Pemerintah (Presiden) dan Dewan Perwakilan Rakyat. ${ }^{7}$

Selanjutnya A. Hamid S. Attamimi juga menelaah pendapat Moh. Kusnardi dan Harmaily Ibrahim yang mengemukakan : Kekuasaan Presiden dalam bidang legislatif merupakan "partner" bagi Dewan Perwakilan Rakyat, yang artinya Presiden bekerjasama dengan Dewan Perwakilan Rakyat dalam tugas legislatif. ${ }^{8}$

Terhadap pendapat Moh. Kusnardi dan Harmaily Ibrahim di atas, A. Hamid S. Attamimi menilai bahwa pendapat para ahli tersebut tidak jelas sama sekali mengenai tugas dan fungsi atau kompetensi Presiden dan DPR dalam pembentukan UndangUndang. Hal ini menurut A. Hamid S. Attamimi dapat ditelusuri dalam mengulas Pasal 5 (1), Pasal 20 (1), dan Pasal 21 ayat (1) UUD 1945, keduanya hanya menyatakan : ...., namun perumusan pasal-pasal tersebut di atas menempatkan Presiden pada perannya yang menonjol dari Dewan Perwakilan Rakyat dalam tugasnya di

\footnotetext{
${ }^{6}$ Ibid, hlm. 147 - 148.

${ }^{7}$ Ibid, hlm. 148.

${ }^{8}$ Ibid, hlm. 149.
}

bidang legislatif....., bahwa Undang-Undang pada hakekatnya adalah membuat suatu kebijakan umum yang dilakukan oleh Presiden, .... ${ }^{9}$

A. Hamid S. Attamimi menilai lebih jauh, bahwa Moh. Kusnardi dan Harmaily Ibrahim secara tidak tepat menguraikan lebih lanjut: Disamping itu, kalau diperhatikan perumusan Pasal 5 ayat (1) dan Pasal 21 ayat(1) Undang-Undang Dasar 1945, maka dapat pula diambil kesimpulan bahwa sebenarnya peranan Presiden lebih menonjol dibandingkan dengan Dewan Perwakilan Rakyat. Kata "memegang kekuasaan" dalam Pasal 5 ayat (1) ini mengandung arti semacam kewajiban. Dengan demikian berarti bahwa Presiden mempunyai kewajiban untuk mengajukan suatu Rancangan Undang-Undang kepada Dewan Perwakilan Rakyat. Kesimpulan ini didasarkan kepada beberapa hal, yaitu (1) Presiden sebagai eksekutif, dan (2) Presiden sebagai Mandataris Majelis Permusyawaratan Rakyat. ${ }^{10}$

Pendapat Moh. Kusnardi dan Harmaily Ibrahim di atas dikatakan A. Hamid S. Attamimi tidak jelas dan dapat pula menjadi rancu ketika menyamakan pengertian memegang keukuasaan membentuk Undang-undang dengan mengajukan Rancangan Undang-undang. Menurut A. Hamid S. Attamimi, menyampaikan rancangan belum membentuk, melainkan baru memulai proses pembentukan. ${ }^{11}$

Selanjutnya upaya "mengkonsultasikan" dari A. Hamid S. Attamimi tidak hanya sampai di situ, ia juga memaparkan pendapat Soerjono Soekanto dan Purnadi

\footnotetext{
${ }^{9}$ Ibid.

${ }^{10}$ Ibid., hlm. 149 - 150.

${ }^{11}$ Ibid., hlm. 150.
} 
Purbacaraka dalam menguraikan kelembagaan negara tingkat pusat yang mengemukakan tanpa penjelasan lebih lanjut apa yang dimaksud dengan kalimat: Dewan Perwakilan Rakyat sebagai peran serta pembuat Undang-Undang bukan badan legislatif. ${ }^{12}$

Abu bakar Busro dan Abu Daud Busroh nampaknya mengikuti Moh. Kusnardi dan Harmaily Ibrahim dengan mengatakan: Jelaslah bahwa dalam kerja sama dengan Dewan Perwakilan Rakyat dalam tugas legislatifnya ini, antara Presiden dan Dewan Perwakilan Rakyat adalah merupakan partner. .... rumusan pasal-pasal tersebut di atas menempatkan Presiden pada peranannya yang lebih menonjol dari pada DPR. Hal ini logis karena pada akhirnya Presidenlah yang bertanggung jawab kepada MPR tentang penyelenggaraan Pemerintahan. ${ }^{13}$.

Lebih lanjut A. Hamid S. Attamimi berpendapat bahwa perumusan Pasal 5 ayat (1) UUD 1945 itu penting sekali bagi menetapkan tugas dan wewenang atau kompetensi Presiden dan DPR dalam pembentukan Undang-undang. Menurut A. Hamid S. Attamimi, kata-kata "memegang kekuasaan" dalam ketentuan Pasal 5 ayat (1) haruslah diartikan "memegang kewenangan", karena dalam kekuasaan (macht), dalam hal ini kekuasaan pembentuk Undang-undang (wetgevende macht), memang mengandung kewenangan membentuk undang-undang. ${ }^{14}$

Untuk mendukung pendapatnya A. Hamid S. Attamimi mengutip pendapat Kranenburg, dalam kepustakaan hukum tata

\footnotetext{
${ }^{12}$ Ibid.

${ }^{13}$ Ibid., hlm. 150-151

${ }^{14}$ Ibid., hlm. 151
}

negara terdapat beberapa perbedaan pendapat mengenai pengertian kata macht dalam kata-kata wetgevende macht yang ditimbulkan oleh berbagai sebab. Sebab yang pertama karena dalam rangka mengikuti jejak Montesquieu, istilah macht telah digunakan dalam dua arti, yaitu functie (fungsi) dan orgaan (badan atau lembaga). Sebab yang kedua, yang berkaitan dengan sebab pertama, pelaksanaan fungsi-fungsi wetgeving (legislatif), uitvoering (eksekutif, dan rechtspraak (yudikatif) menentukan persyaratan yang berbeda-beda kepada organ-organ (badan-badan atau lembagalembaga) tersebut, sehubungan dengan kehidupan masyarakat yang intern dan ekstern. ${ }^{15}$

Maka dengan mendasarkan pendapat Kranenburg di atas, A. Hamid S. Attamimi kemudian menyatakan tidak dapat lain kecuali mengartikan kata "kekuasaan" (macht) dalam Pasal 5 ayat (1) UUD 1945, dengan fungsi. Sebabnya ialah karena UUD 1945 tidak menganut sistem pemisahan kekuasaan seperti yang diajarkan oleh Montesquieu, dan selanjutnya karena dalam pelaksanaan fungsi tersebut UUD 1945 menyebutkannya "dengan persetujuan Dewan Perwakilan Rakyat", yakni tidak dilaksanakan oleh Presiden sendiri begitu saja. Dengan perkataan lain, menurut A. Hamid S. Attamimi kekuasaan pembentukan Undang-undang sesungguhnya ada pada Presiden. Dan agar produk yang diharapkan, yakni Undang-undang, dapat terbentuk maka dalam melaksanakan keuasaannya tersebut Presiden memerlukan persetujuan DPR. ${ }^{16}$.

\footnotetext{
15 Ibid., hlm. 151-152

${ }^{16}$ Ibid., hlm. 152
} 
Berbeda dengan A. Hamid S. Attamimi, Bagir Manan ${ }^{17}$ malah mempertanyakan apakah secara material, memang Presiden lebih utama sebagai lembaga legislatif, hal ini mengingat:

Pertama: Dalam kata "dengan persetujuan" sekaligus terkandung wewenang "dapat tidak menyetujui". Wewenang untuk tidak menyetujui menunjukan adanya "keseimbangan: (balancing) antara Presiden dan DPR.

Kedua, UUD 1945 mengakui hak inisiatif DPR (Pasal 21). Dalam hal Rancangan Undang-undang berasal dari DPR, maka secara tersirat Presiden yang memberikan persetujuan dengan cara mengesahkan RUU tersebut menjadi Undang-undang. Dengan demikian dari ajaran yang lebih menekankan fungsi daripada kelembagaan pemerintahan negara, maupun makna material dari ketentuan UUD 1945 mengenai pembentukan undangundang, tidaklah berlebihan kalau penjelasan Pasal 5 UUD 1945 menyebutkan: Presiden bersama-sama dengan Dewan Perwakilan Rakyat menjalankan "legislative power" dalam negara.

Pendapat lain dikemukakan Suwoto Mulyosudarmo dengan melihat kepada kedudukan Presiden dalam kapasitas sebagai kepala eksekutif dan selaku kepala negara yang menilai ketentuan Pasal 5 ayat (1) jo Pasal 20 ayat (2) UUD 1945, dapat ditafsirkan bahwa yang memiliki kekuasaan membuat undang-undang adalah Presiden selaku kepala eksekutif dan pengesahannya dilakukan oleh Presiden selaku kepala negara. Kekuasaan membuat undangundang berada pada Presiden. Proses

${ }^{17}$ Bagir Manan, Dasar-Dasar Perundang-Undangan Indonesia, Jakarta: Ind-Hill.co 1992, hlm. 36 pembuatannya diajukan oleh Presiden selaku kepala eksekutif dan memerlukan persetujuan Dewan Perwakilan Rakyat. Persetujuan Dewan Perwakilan Rakyat ini sangat penting, sebab ikut secara material menentukan substansi undang-undang. Di Indonesia tidak terbuka kemungkinan Dewan Perwakilan Rakyat, tanpa persetujuan Presiden, menetapkan undangundang. Keadaan ini membuktikan bahwa UUD 1945 tidak melaksanakan sistem pemisahan kekuasaan. Pembuatan undangundang di Indonesia menerapkan sistem kekuasaan terpadu. Kekuasaan antara Presiden selaku kepala eksekutif sebagai unsur pelaksana undang-undang, dan DPR sebagai badan politik yang diberi kekuasaan memberikan persetujuan rancangan undangundang, serta Presiden yang secara formal diberi kekuasaan pengesahan undangundang $^{18}$

Konfigurasi paparan pendapat para pakar hukum tata negara di atas dikemukakan dalam menilai format kekuasaan membentuk undang-undang berdasarkan sudut pandangan dengan mengacu kepada ketentuan konstitusi lama, Undang-Undang Dasar 1945 sebelum dilakukan perubahan-perubahan.

Sebagaimana telah diuraikan di muka bahwa konstitusi perubahan ini menempatkan Presiden dengan hak untuk mengajukan Rancangan Undang-Undang kepada Dewan Perwakilan Rakyat (Pasal 5 ayat 1 Undang-Undang Dasar 1945 hasil perubahan). Walaupun kekuasaan pembentukan undang-undang ada di tangan Dewan Perwakilan Rakyat, ketentuan

18 Suwoto Mulyosudarmo, Peralihan Kekuasaan, Kajian Teoritis dan Yuridis terhadap Pidato Nawaksara, Jakarta: Gramedia Pustaka Utama, 1997, hlm. 33-34 
perubahan Undang-Undang Dasar tetap menempatkan kebersamaan antara Dewan Perwakilan Rakyat dan Presiden dalam hal membahas setiap rancangan undang-undang. Ketentuan ini secara tegas dinyatakan dalam Pasal 20 ayat (2) Undang-Undang Dasar 1945 hasil perbahan: Setiap rancangan undang-undang dibahas oleh Dewan Perwakilan Rakyat dan Presiden untuk mendapat persetujuan bersama (cetak tebal dari penulis).

Kata-kata mendapat persetujuan bersama berarti bahwa Dewan Perwakilan Rakyat dan Presiden mencari kesepakatan atau titik temu terhadap teknis dan substansi atas rancangan undang-undang. Sehingga ketika kesepakatan dan titik temu telah tercapai dan terjadi maka rancangan undang-undang telah mendapat persetujuan bersama. Pasal inilah yang bisa dikatakan bahwa praktek lama pembahasan setiap rancangan undangundang masih harus memerlukan pembahasan secara bersama antara Dewan Perwakilan Rakyat dan Presiden. Untuk mengantisipasi "kebuntuan" mendapat persetujuan bersama di atas dalam ayat (3) nya dinyatakan Jika rancangan undangundang itu tidak mendapat persetujuan bersama, rancangan undang-undang itu tidak boleh diajukan lagi dalam persidangan Dewan Perwakilan Rakyat masa itu. Katakata "tidak mendapat persetujuan bersama" di atas maksudnya bisa keberatan untuk menyetujui itu datang dari Dewan Perwakilan rakyat dan bisa datang dari Presiden.

Berdasarkan format demikian maka tidaklah tepat apabila dikatakan bahwa Undang-Undang Dasar 1945 hasil perubahan telah menganut prinsip pemisahan kekuasaan (separation of power) karena ternyata bahwa terhadap fungsi legislatif telah dilakukan oleh dua organ yakni Dewan Perwakilan Rakyat dan Presiden. Walaupun kedudukan Dewan Perwakilan Rakyat lebih menonjol atau lebih utama untuk mengajukan rancangan undang-undang sebagai konsekwensi ketentuanPasal 20 ayat (1) Undang-Undang Dasar 1945 hasil perubahan yang baru.

Dengan telah mendapat persetujuan bersama, maka naskah rancangan undangundang yang telah disetujui tadi tinggal dilakukan pengesahannya. Dalam hal pengesahan inilah Konstitusi hasil perubahan telah mengatur dalam ketentuan Pasal 20 ayat (4) Undang-Undang Dasar1945: Presiden mengesahkan rancangan undang-undang yang telah disetujui bersama untuk menjadi undangundang. Ketentan Pasal 20 ayat (4)di atas ternyata masih ditambahkan dengan ketentuan Pasal 20 ayat (5) nya yang menyetakan: Dalam hal rancangan undangundang yang telah disetujui bersama tersebut tersebut tidak disahkan oleh Presiden dalam waktu tiga puluh hari semenjak rancangan undang-undang disetujui, rancangan undang-undang tersebut sah menjadi undang-undang dan wajib diundangkan.

Dari konstruksi ketentuan Pasal 20 ayat (5) Undang-Undang Dasar 1945 hasil perubahan itulah tampak bahwa posisi Dewan Perwakilan Rakyat adalah kuat/menonjol (legislative heavy) dibanding Presiden. Pasal 20 ayat (5) ini seolah mem fait a compli Presiden atau dengan kata lain bahwa hak veto justru berada pada Dewan Perwakilan Rakyat dengan sendirinya dari klausul Pasal 20 ayat (5) di atas dengan menjadikan sah suatu rancangan undang- 
undang yang apabila melebihi tiga puluh hari semenjak disetujui bersama, Presiden belum mengesahkannya. Bukan hanya sah menjadi undang-undang saja tetapi juga wajib diundangkan. Walaupun sebenarnya, apabila kita telaah bahwa posisi Presiden tidaklah diperkenankan untuk tidak mengesahkan rancangan undang-undang tadi, karena bukankah ia juga ikut terlibat andil dalam pembahasan bersama-sama di forum Dewan Perwakilan Rakyat. Kalau toh sebenarnya bukanlah Presiden secara fisik hadir dalam forum pembahasan bersama dengan Dewan Perwakilan Rakyat, tetapi yang mewakili adalah menteri yang ditunjuk oleh Presiden yang senantiasa melaporkan dan mengkonsultasikan hasil-hasil perkembangan pembahasan di forum bersama Dewan Perwakilan Rakyat.

Dalam kenyataan yang terjadi pernah Presiden tidak mengesahkan suatu rancangan undang-undang yang disetujui bersama oleh kedua belah pihak tadi, yakni rancangan Undang-undang Penyiaran yang cukup menghebohkan dunia politik Indonesia pada bulan Juni 1997. Akan tetapi dalam hal Presiden tidak atau belum mensahkan suatu rancangan undang-undang yang disetujui bersama juga merupakan hal yang wajar saja apabila kita telusuri konteksnya dalam sistem demokrasi dan konstelasi politik di Dewan Perwakilan Rakyat. Bahwa putusan untuk mengambil persetujuan bersama dilakukan melalui proses persidangan. Bisa saja terjadi meskipun pemerintah berbeda pendapatnya dengan kekuatan oposisi di Dewan Perwakilan Rakyat, tetapi dalam pengambilan putusan akhir pembahasan suatu rancangan undang-undang ternyata dimenangkan oleh kelompok oposisi tersebut. Sudah barang tentu Presiden dihadapkan kepada dua pilihan mengesahkan atau tidak mengesahkan rancangan undang-undang tersebut. Dalam keadaan demikian adalah wajar Presiden menolak mengesahkan dan penolakan inilah yang disebut hak veto Presiden.

Untuk perbandingan, di Inggeris, raja berhak menolak rancangan UU yang sudah disetujui Parlemen. Tapi, sudah hampir 100 tahun terakhir Raja tidak pernah menolak hal itu lagi. Meskipun secara hukum raja berhak menolak taapi dalam proses demokrasi dia mengatakan, saya harus menghormati kehendak parlemen sebagai kehendak rakyat. ${ }^{19}$ Demikian pula dengan sistem Amerika Serikat, Presiden diberi hak untuk menolak mengesahkan undangundang yang disetujui Kongres yang disebut hak veto karena Presiden tidak ikut membuat Undang-Undang. Ini model Amerika dalam rangka pemisahan kekuasaan yang murni. ${ }^{20}$ Tetapi hak veto ini dapat dikesampingkan dengan cara pemungutan suara ulang atas rancangan undang-undang yang telah disetujui Kongres. ${ }^{21}$ Apabila dalam pemungutan suara ulang disetujui sekurang-kurangnya dua pertiga anggota, maka rancangan undangundang tersebut akan menjadi undangundang tanpa memerlukan persetujuan Presiden. Selain melalui sistem pemungutan ulang tersebut, hak Presiden untuk mengesahkan atau menolak juga dibatasi oleh waktu. Dalam UUD Pasal 1 ayat (6)

\footnotetext{
${ }^{19}$ Ibid., hlm. 64

20 Bagir Manan, "Reformasi Konstitusi menuju Keseimbangan Kewenangan Eksekutif dan Legislatif', Jurnal Civility, Jakarta, Vol. No. 1 JuliSeptember 2001, hlm. 74

21 Bagir Manan, Lembaga, Kepresidenan, Yogyakarta: Gama Media \& Pusat Studi Hukum UII, 1999, hlm 129 - 130
} 
angka 2 antara lain disebutkan: " if any Bill shall be returned by the President withis ten days (Sunday excepted) after it shall have been presented to him, the some shall be a law, in like manner as if he had signed it, unless the Congress by their adjournment prevent it return, is which case it shall not be a law". 22

Mekanisme untuk mengambil putusan ulang dengan pemungutan suara di Dewan Perwakilan Rakyat seperti halnya dalam Konstitusi Amerika Serikat tidak ada dalam Undang-Undang Dasar1945 hasil perubahan. Seyogyanya mekanisme di atas juga ditempuh oleh Undang-Undang Dasar 1945 hasil perubahan.

Terhadap ketentuan Pasal 20 ayat (5) Undang-Undang Dasar 1945 hasil perubahan di atas, apabila kita telusuri sewaktu dibicarakan di dalam forum pembahasan Panitia Ad Hoc III BP MPR terjadi perdebatan dan permunculan pendapat yang sangat beragam. Tetapi penulis melihatnya bahwa suasana yang sudah sangat kuat mengental pada diri anggota-anggota Majelis Permusyawaratan Rakyat pada ketika itu adalah keinginan kuat untuk memberdayakan lembaga legislatif, lembaga parlemen Dewan Perwakilan Rakyat dengan berkaca kepada pengalaman ke belakang dalam ketentuan Konstitusi sebelum perubahan dan praktek ketatanegaraan yang lama bahwa kedudukan Presiden adalah lebih kuat (executive heavy) dibanding dengan Dewan Perwakilan Rakyat. Kondisi inilah yang ingin dibalik keadaannya seperti yang diistilahkan oleh Bagir Manan ketika tadinya kita merasa serba eksekutif, sekarang seolah-olah bandul

${ }^{22}$ Ibid, hlm. 147 - 148 dibalikkan serba legislatif. ${ }^{23}$ sehingga diakui oleh Bagir Manan, sebagai seorang ahli hukum tata negara, dia merasa bingung mengenai perkembangan semacam ini. ${ }^{24}$

Dengan meminjam "semangat" dari suasana kebingungan pakar hukum tata negara seperti Bagir Manan di atas, maka penulis berpendapat bahwa Majelis Permusyawaratan Rakyat terlalu tergesagesa untuk memutuskan rumusan Pasal 20 ayat (5) Undang-Undang Dasar 1945 sebagai hasil perubahan.

Apabila kita menelaah naskah tawaran dari hasil kompilasi ikhwal Bab tentang Dewan Perwakilan Rakyat yang disodorkan dalam pembicaraan di Panitia Ad Hoc III BP MPR, pada awalnya khusus berkenaan dengan Pasal 20 ayat (5) belum muncul dalam kompilasi. Rumusan kompilasi yang disodorkan waktu itu adalah dalam rangkaian sebagai berikut:

Pasal 20 ayat (1) : Dewan Perwakilan Rakyat memegang kekuasaan membentuk Undang-Undang.

Ayat (2) tiap-tiap undang-undang memerlukan persetujuan Presiden.

Ayat (3) Apabila dalam waktu 30 hari setelah rancangan undang-undang yang disahkan oleh Dewan Perwakilan Rakyat tidak mendapat persetujuan Presiden, maka rancangan undang-undang itu sah menjadi undang-undang.

Ayat (4) Dalam hal Presiden dengan alasan yang kuat menolak menyetujui suatu rancangan undang-undang yang sudah di sahkan oleh Dewan Perwakilan

\footnotetext{
${ }^{23}$ Ibid. hlm. 75

${ }^{24}$ Ibid.
} 
Rakyat, maka putusan diserahkan pada Majelis Permusyawaratan Rakyat. ${ }^{25}$

Dari pembahasan dan perkembangan pemikiran muncul pendapat yang menarik terhadap rumusan pasal ini, seperti yang pernah dikemukakan Harjono:

... jika dalam waktu 30 hari setelah RUU yang disepakati ini karena ada naskah kesepakatannya oleh DPR bersama Presiden tidak disahkan oelh Presiden Konsep yang lama kan diajukan ke MPR... maka timbul ide baru menurut saya bagaimana kalau Mahkamah Agung kita dilibatkan untuk mengesahkan... Mahkamah Agung juga akan melihat prosesnya secara formal apa sudah benar apakah sudah ada naskah kesepakatan dan lain sebagainya. $^{26}$

Pendapat penulis agak sedikit berbeda dengan pendapat Harjono walaupun keinginan substantif yang sama untuk menyerahkan kepada satu lembaga yang bukan MPR tapi mempunyai kompetensi yang jelas untuk menilai yakni suatu Mahkamah. Apabila Harjono menyerahkannya kepada Mahkamah Agung, maka penulis berpendapat bahwa hal itu perlu diserahkan kepada Mahkamah Konstitusi. Dengan demikian kepada Mahkamah Konstitusi diberikan juga wewenang untuk menerima permohonan dari pihak Presiden maupun Dewan Perwakilan Rakyat untuk menguji materi rancangan undang-undang tersebut terhadap Undang-Undang Dasar.

\footnotetext{
${ }^{25}$ Sekretariat MPR RI, Risalah Rapat Badan Pekerja Panitia Ad Hoc II Sidang umum MPR RI, Buku Kedua Jilid 6, Jakarta, 1999 , hlm. 305

${ }^{26}$ Ibid., hlm. 441
}

Sekedar perbandingan di Perancis sebelum rancangan Undang-Undang yang telah disetujui parlemen dapat berlaku Presiden dapat mengajukan ke Mahkamah Konstitusi untuk melakukan pengkajian apakah bertentangan atau tidak dengan Undang-UndangDasar. Apabila pendapat Mahkamah Konstitusi adalah positif maka barulah rancangan undang-undang itu ditingkatkan menjadi undang-undang dengan mengundangkannya dalam lembaran negara. Apabila pendapat Mahkamah Konsitusi bersifat negatif maka rancangan undang-undang dikembalikan kepada parlemen untuk diperbaharui. Inilah yang dinamakan pengkajian preventif. Sebelum suatu undang-undang dapat diberlakukan harus terlebih dahulu diuji oleh conseil constutitionel apakah memuat hal-hal yang bertentangan dengan Undang-Undang Dasar. $^{27}$

Sementara itu dalam memberikan makna atas frasa ikut membahas berkenaaan dengan kewenangan Dewan Perwakilan Daerah sebagaimana ditegaskan dalam Pasal 22D ayat (2), Mahkamah Konstitusi telah memberikan pertimbangannya bahwa berdasarkan ketentuan tersebut, DPD sebagai lembaga negara yang mempunyai hak dan / atau kerwenangan yang sama dengan DPR dan Presiden dalam membahas RUU yang berkaitan dengan otonomi daerah; hubungan pusat dan daerah; pembentukan, pemekaran, dan penggabungan daerah; pengelolaaan sumber daya alam dan sumber dauya ekonomi

27 T. Koopmans, Compendium van Staatsrecht (diolah kembali oleh th. Bellekom,A.W. Heringa, T. Koopmans, dan R.E. de Winter), Deventer, Kluwer, Achtste druk, 1998, hlm. 243 
lainnya; serta perimbangan keuangan pusat dan daerah. ${ }^{28}$

Penggunaan frasa "ikut membahas" dalam Pasal 22D ayat (2) UUD 1945 karena Pasal 20 ayat (2) UUD 1945 telah menentukan secara tegas bahwa setiap RUU dibahas oleh DPR dan Presiden untuk mendapat persetujuan bersama. Penggunaan frasa "ikut membahas" adalah wajar karena Pasal 20 ayat (2) UUD 1945 disahkan pada Perubahan Pertama UUD 1945 tahun 1999, sedangkan Pasal 22D UUD 1945 disahkan pada Perubahan Ketiga UUD 1945 pada tahun 2001. Hal itu berarti bahwa, "ikut membahas" harus dimaknai DPD ikut membahas RUU yang berkaitan dengan otonomi daerah; hubungan pusat dan daerah; pembentukan, pemekaran, dan penggabungan daerah; pengelolaan sumber daya alam dan sumber daya ekonomi lainnya; serta perimbangan keuangan pusat dan daerah, bersama DPR dan Presiden. Dengan demikian, pembahasan RUU harus melibatkan DPD sejak memulai pembahasan pada Tingkat I oleh Komisi atau Panitia Khusus DPR, yaitu sejak menyampaikan pengantar musyawarah, mengajukan, dan membahas Daftar Inventaris Masalah (DIM) serta menyampaikan pendapat mini sebagai tahap akhir dalam pembahasan di Tingkat I. Kemudian DPD menyampaikan pendapat pada pembahasan Tingkat II dalam rapat paripurna DPR sampai dengan sebelum tahap persetujuan.

Menurut Mahkamah, pembahasan RUU dari DPD harus diperlakukan sama dengan RUU dari Presiden dan DPR. Terhadap RUU dari Presiden, Presiden diberikan kesempatan memberikan penjelasan,

28 Lihat Putusan Mahkamah Konstitusi Nomor: 92/PUU-X/2012 sedangkan DPR dan DPD memberikan pandangan. Begitu pula terhadap RUU dari DPR, DPR diberikan kesempatan memberikan penjelasan, sedangkan Presiden dan DPD memberikan pandangan. Hal yang sama juga diperlakukan terhadap RUU dari DPD, yaitu DPD diberikan kesempatan memberikan penjelasan, sedangkan DPR dan Presiden memberikan pandangan. Konstruksi UUD 1945 mengenai pembahasan RUU antaraPresiden dan DPR, serta DPD (dalam hal terkait RUU tertentu) dilakukan antara lembaga negara, sehingga DIM, diajukan oleh masing-masing lembaga negara, dalam hal ini bagi DPR seharusnya DIM diajukan oleh DPR, bukan DIM diajukan oleh fraksi. Walaupun demikian, Mahkamah dapat memahami bahwa mekanisme pembahasan RUU dengan membahas DIM yang diajukan oleh fraksi adalah praktik pembahasan RUU sebelum perubahan UUD 1945. Selanjutnya pembahasan pada tingkat Alat Kelengkapan DPR yang sudah mengundang Presiden dan/atau sudah mengundang DPD, maka DPR dalam pembahasan DIM hanya diwakili oleh Alat Kelengkapan DPR sebagai satu kesatuan kelembagaan. ${ }^{29}$

Sebenarnya untuk mendudukkan kedudukan atau posisi yang sama antar kelembagaan DPD, Presiden dan DPD (dalam hal RUU tertentu) untuk melakukan pembahasan bersama, walaupun ketentuan Pasal 20 ayat (2) UUD 1945 telah dilakukan dalam Perubahan Pertama, tetapi seyogianya perumusan Pasal 22D ayat (2) dirumuskan oleh MPR pada waktu Perubahan Ketiga dengan rumusan: Rancangan undangundang yang berkaitan dengan otonomi daerah; hubungan pusat dan daerah;

${ }^{29}$ Ibid. 
pembentukan, pemekaran, dan penggabungan daerah; pengelolaaan sumber daya alam dan sumber dauya ekonomi lainnya; serta perimbangan keuanghan pusat dan daerah, dibahas oleh DPR, Presiden, dan DPD untuk mendapat persetujuan bersama. Sehingga frasa atau kata "ikut" yang seolah melemahkan posisi DPD tidak terjadi.

\section{KESIMPULAN}

Rumusan atau konstruksi konstitusi berkenaan dengan kekuasaan pembentukan undang-undang yang melibatkan tiga lembaga negara DPR, Presiden, dan DPD tidak didesain dalam suatu desain konstitusi yang utuh dan bagus. Perlu suatu desain konstitusi yang utuh dan elegan menempatkan tiga lembaga negara DPR, Presiden, dan DPD untuk dituangkan dalam UUD 1945 menyangkut hubungan kelembagaan dalam suatu pembentukan undang-undang dan pembahasan suatu RUU.

\section{DAFTAR PUSTAKA}

\section{Buku dan Artikel Ilmiah}

Attamimi, A. Hamid S.,1990, Peranan Keputusan Presiden Republik Indonesia Dalam Penyelenggaraan Pemerintahan Negara Suatu Analisis Mengenai Keputusan Presiden Yang Berfungsi Pengaturan Dalam Kurun Waktu Pelita I - Pelita IV” Disertasi, Jakarta, Universitas Indonesia.

Manan, Bagir, Dasar-Dasar PerundangUndangan Indonesia, Jakarta: IndHill.co, 1992.

\section{Lembaga,Kepresidenan,}

Yogyakarta, Gama Media \& Pusat Studi Hukum UII, 1999.

\section{--------------, “Reformasi Konstitusi Menuju Keseimbangan Kewenangan Eksekutif dan Legislatif", Jurnal Civility, Jakarta, Vol. No. 1 Juli- September 2001.}

Mulyosudarmo dan Suwoto, Peralihan Kekuasaan, Kajian Teoritis dan Yuridis terhadap Pidato Nawaksara, Jakarta, Gramedia Pustaka Utama, 1997.

PPUU-DPD RI, 2015, Prolegnas Usul DPD RI Tahun 2015-2019, Prioritas 2015 dan Hasil Pembahasan Tripartit (DPR, DPD dan Pemerintah) Tahun 2015 - 2019 Prioritas Tahun 2015, Jakarta, PPUU-DPD RI.

Sekretariat Jenderal MPR RI, Risalah Rapat Badan Pekerja antyiai Ad Hoc II Sidang Umum MPR RI, Jakarta, Buku Kedua Jilid 6, 1999.

T. Koopmans, Compendium van Staatsrecht (diolah kembali oleh Th. Bellekom, A.W. Heringa, T. Koopmans, dan R.E. de Winter),1998, Deventer, Kluwer, Achtste druk, 1998.

\section{Peraturan Perundang-Undangan}

Undang-Undang Dasar Negara RI Tahun 1945

Putusan Mahkamah Konstitusi Nomor: 92/PUU-X/2012 